\title{
COLETIVISMO AGRÁRIO E TENDÊNCIAS INDIVIDUALISTAS NA FRANÇA PRÉ-REVOLUCIONÁRIA'
}

\author{
Laurent de Saes \\ Doutorando em História Social - FFLCH/USP
}

\begin{abstract}
Resumo
Na França do século XVIII, a terra ainda era fortemente marcada pela presença de direitos e servidões coletivas que limitavam a autonomia dos proprietários rurais, e pela existência de bens comunais, propriedades coletivas dos habitantes das comunas rurais. Essas instituições foram alvo, durante as últimas décadas do século, de uma forte tendência individualista que, em larga medida, prenunciou a legislação revolucionária.
\end{abstract}

\section{Pallavras-chave}

propriedade rural $\bullet$ direitos coletivos $\bullet$ bens comunais.

\section{Abstract}

In $18^{\text {th }}$ century France, land was still very much marked by the existence of collective rights and restrictions which limited the autonomy of landowners, and by the presence of common fields, that is, collective properties of the inhabitants of rural communes. During the last decades of the century, those institutions became the target of a strong individualist trend that, in a large measure, foretold the revolutionary legislation.

\section{Keywords}

rural property $\bullet$ collective rights $\bullet$ common fields.

\footnotetext{
${ }^{1}$ A pesquisa que gerou o presente artigo foi realizada com o auxílio da Fundação de Amparo à Pesquisa do Estado de São Paulo (Fapesp).
} 
Ao longo dos anos que marcaram a Revolução francesa, algumas questões estiveram no centro dos debates legislativos nas assembleias revolucionárias. Dentre elas, a questão da propriedade assumiu uma particular importância. Isso porque a Revolução havia herdado do Antigo Regime a tarefa de reformular e reconstruir o direito individual de propriedade, tal como ele havia sido consagrado pelo direito romano: um direito absoluto e individualizado. Isso implicava, por um lado, derrubar as sobrevivências do regime feudal da propriedade, mas implicava também uma ofensiva contra o caráter coletivo da propriedade rural tradicional. Esse coletivismo agrário manifestava-se pela incidência de direitos e servidões coletivas sobre as terras particulares, limitando o direito do proprietário sobre o seu bem, e pela existência de bens comunais, isto é, bens coletivos cuja titularidade cabia à comuna rural e que eram, em princípio, coletivamente explorados pelos seus habitantes. Essas instituições de direito comunitário determinavam a própria estrutura da produção agrícola e repercutiam substancialmente na evolução econômica do país.

Procuraremos, no presente artigo, traçar um quadro do coletivismo agrário na França do final do Antigo Regime para, num segundo momento, confrontá-lo à forte tendência individualista que precedeu e, de certa forma, prenunciou as transformações revolucionárias.

\section{Coletivismo agrário e limitação do direito de propriedade}

A organização da agricultura na França do Antigo Regime, ainda bastante arcaica, girava em torno da comuna rural. Esta se definia, no espaço, "pelos limites de um terreno sujeito a diversas regras de exploração comuns (regulamentos de cultura temporária, de pastoreio sobre o comunal, datas de ceifa etc.) e, sobretudo, a servidões coletivas em proveito do grupo dos habitantes". 2 Assim, a agricultura antiga, profundamente marcada por uma mentalidade comunitária, sustentava-se sobre uma concepção de propriedade muito distante da forma individualista que a Revolução lhe daria. Era, ao contrário, dotada de um forte caráter coletivo que, na prática, manifestava-se pela existência de bens comunais e, sobretudo, por direitos de uso e servidões coletivas que incidiam sobre as terras particulares.

${ }^{2}$ BLOCH, Marc. Les caractères originaux de l'histoire rurale française. Paris: Librairie Armand Colin, 1960, p. 173. 
Toda a exploração da terra era organizada a partir dessas instituições de direito coletivo. ${ }^{3}$ Esse tipo de organização explicava-se, em grande medida, pela forma de ocupação do solo que dava aos campos franceses um desenho bastante peculiar e favorável ao desenvolvimento de uma agricultura de tipo coletivista. Deve-se ressaltar que a paisagem rural não era a mesma em todo o território: dependendo da região, o terreno apresentava um formato diferente, ao qual correspondia um regime agrário específico.

O regime agrário consistia num conjunto de normas técnicas e jurídicas que, por força da lei ou tão-somente da tradição, impunham-se a cada grupo ou coletividade de extensão média. ${ }^{4}$ Marc Bloch aponta que a agricultura francesa era marcada pela existência de três regimes agrários distintos: o regime de campos abertos e alongados; o regime de campos abertos e irregulares; e o regime de campos cercados. ${ }^{5} \mathrm{O}$ que, na prática, marcava a diferença entre um regime e outro era essencialmente o peso das servidões coletivas sobre as terras individuais.

Nas regiões de campos cercados, situadas, sobretudo, no oeste e no centro do país, o peso dos costumes era muito reduzido. As terras eram protegidas por muros e cercas vivas e a propriedade era extremamente individualizada: o proprietário era senhor absoluto de seus bens, podendo explorá-los como bem entendesse. Esse regime, embora bastante disperso, podia ser encontrado em regiões onde a terra era pouco fértil, como na Bretanha, na Normandia e no Maciço Central. ${ }^{6}$

A maior parte do território francês, entretanto, submetia-se aos regimes de campos abertos, caracterizados pela ausência de cercas nas propriedades particulares. $\mathrm{O}$ regime de campos abertos e irregulares vigorava nas regiões onde as parcelas assumiam formas variadas e eram dispostas como que ao acaso nas glebas. Nesse regime, que prevalecia no Midi, as servidões coletivas existiam, mas a sua aplicação era pouco rigorosa: ao longo do século XVIII, os hábitos coletivos cederam cada vez mais o lugar a práticas individualistas que encontravam, no formato geralmente alargado das parcelas, um campo propício.

\footnotetext{
${ }^{3}$ Albert Soboul chegou a definir a comunidade rural como um "modo de produção pré-capitalista", mas depois voltaria atrás, ao afirmar que a comunidade não é modo, mas o "quadro da produção", estando integrada ao modo de produção feudal e permitindo também, no seu interior, a constituição de elementos do modo capitalista de produção (Problèmes paysans de la révolution 1789-1848. Paris: François Maspero, 1983, p. 213).

${ }^{4}$ BLOCH, Marc. O problema dos regimes agrários. In: A terra e seus homens: Agricultura e vida rural nos séculos XVII e XVIII. Bauru, SP: Edusc, 2001a, p. 136.

${ }^{5}$ BLOCH, Marc, ibidem, p. 140-144.

${ }^{6}$ BLOCH, Marc, ibidem, p. 144-145.
} 
O espírito comunitário continuava, por outro lado, bastante vivo nas regiões de campos abertos e alongados. Nelas, os lotes eram dispostos em feixes regulares, estreitos e alongados. ${ }^{7}$ Cada parcela tinha seu próprio dono, mas este não tinha autonomia absoluta para fazer dela o que quisesse. Tratava-se de um regime de tipo comunitário, que Laurière, famoso jurista do Antigo Regime, descreveu da seguinte forma: "Pelo direito geral da França, as heranças só estão protegidas e acauteladas quando os frutos estão em cima, e desde que sejam colhidos, a terra, por uma espécie de direito das gentes, torna-se comum a todos os homens, ricos ou pobre, igualmente". ${ }^{8} \mathrm{Ou}$ seja, uma vez colhidos os produtos, a propriedade individual cessava e a terra assumia a forma de um bem coletivo. Laurère referia-se claramente à vaine pâture, instituto basilar do direito agrário antigo e principal limitação ao exercício da propriedade.

$\mathrm{Na}$ agricultura tradicional, havia sempre uma enorme preocupação com a criação de animais, na medida em que eles forneciam todo o adubo necessário para a cultura de grãos. O problema fundamental era alimentá-los. Para isso, recorria-se aos prados naturais (pouco numerosos naquela época), às terras comunais e, sobretudo, aos campos particulares em pousio. Uma vez realizada a colheita, a terra não ficava inutilizada: o restolho (hastes, ervas daninhas) servia para a alimentação dos animais, e não apenas os do proprietário da parcela, mas os de toda a comunidade, reunidos em um rebanho comum. A vaine pâture era justamente esse direito coletivo de pastagem que dava aos habitantes da comuna a faculdade recíproca de conduzirem os seus animais aos pastos alheios para alimentá-los. ${ }^{9}$ Assim, após a primeira colheita, os direitos do proprietário sobre o seu bem ficavam suspensos e davam lugar a um direito coletivo dos habitantes das

\footnotetext{
${ }^{7}$ Bloch apresentou uma possível explicação técnica para o desenvolvimento de campos irregulares em certas regiões e campos alongados em outras: o uso do arado, um instrumento fácil de virar, teria permitido a cultura em campos mais irregulares, enquanto a charrua, embora mais fácil de movimentar, pois possuía rodas, não podia mudar de direção facilmente e teria levado à cultura em campos alongados. A distinção seria, portanto, entre regiões de arado e regiões de charrua. O próprio autor, entretanto, questionou a pertinência dessa teoria: a razão poderia estar simplesmente na forma de ocupação do solo, mais regrada ou sem direção. (BLOCH, Marc. O curso de Fontenay. In: A terra e seus homens: Agricultura e vida rural nos séculos XVII e XVIII. Bauru, SP: Edusc, 2001b, p. 231-232). ${ }^{8}$ Citado em BLOCH, Marc, op. cit., 2001a, p. 143.

${ }^{9}$ MALEZIEUX, R; RANDIER, R. Traité de droit rural. Paris: Librairie Générale de Droit et de Jusrisprudence, 1972, p. 422.
} 
comunidades de alimentarem seus animais nos campos individuais. ${ }^{10}$ Esse sistema era absolutamente indispensável à grande maioria dos trabalhadores da terra. ${ }^{11}$

O direito de parcours era uma variante da vaine pâture: dava aos habitantes de uma determinada aldeia o direito de exercer o pasto coletivo na gleba das aldeias vizinhas. ${ }^{12}$ Era algo como uma vaine pâture recíproca entre as comunidades aldeãs.

Para que o pastoreio coletivo fosse possível, era necessário que os campos não fossem protegidos por cercas ou fossas que impedissem a circulação dos animais. O proprietário ficava, com isso, proibido de cercar as suas terras, ou pelo menos de fechá-las permanentemente. ${ }^{13}$ Essa proibição era o corolário da exploração comunitária da terra e fazia a especificidade dos regimes de campos abertos. ${ }^{14}$

Além disso, o pasto coletivo só podia ser realizado durante o pousio, ou seja, o período em que a terra era deixada em recuperação, para que fosse preservada a sua fertilidade. O pousio atendia, portanto, a uma dupla finalidade: recomposição da terra e alimentação dos animais da comunidade. Era assim necessário que os agricultores respeitassem um calendário preciso que levasse em conta a forma e a disposição das parcelas. A exploração da terra submetia-se, assim, ao princípio do afolhamento forçado (assolement forcé). ${ }^{15}$

$\mathrm{O}$ afolhamento consistia na divisão de cada exploração em partes distintas, cada uma delas com uma destinação específica. Esse sistema podia ser de dois tipos: bienal ou trienal. O afolhamento bienal implicava um ano de exploração da terra para um ano de pousio. O objetivo era que, durante um mesmo ano, metade da parcela permanecesse sob cultura e metade ficasse vazia e, portanto, à disposição do pasto coletivo. $\mathrm{O}$ afolhamento trienal, mais elaborado, consistia na divisão da exploração em três porções (soles) de tamanhos semelhantes: a

\footnotetext{
${ }^{10}$ BLOCH, Marc. A luta pelo individualismo agrário na França do século XVIII. In: A terra e seus homens: Agricultura e vida rural nos séculos XVII e XVIII. Bauru, SP: Edusc, 2001c, p. 272.

${ }^{11}$ Esse sistema, absolutamente necessário nas regiões de campos abertos, era dispensável nas de campos cercados, onde as porções cultivadas eram geralmente bastante reduzidas. Os camponeses dessas regiões, como os bretões, alimentavam seus animais geralmente nas terras comunais, o que explica a sua resistência ao movimento de partilha desses bens durante o século XVIII (BLOCH, Marc, op. cit., 2001b, p. 233).

${ }^{12}$ MALEZIEUX, R; RANDIER, R., op. cit., 1972, p. 423.

${ }^{13}$ Entre a semeadura e a colheita, era possível o cercamento temporário da parcela: esse era justamente o período em que o direito do proprietário sobre o seu bem era absoluto.

${ }^{14}$ Cercas não eram somente proibidas como eram muitas vezes inviáveis: o perímetro a cercar era demasiadamente extenso, o que tornava as cercas caras demais para a maioria dos camponeses; as cercas produziriam sombra sobre os campos, o que impediria o crescimento das plantas; a colheita poderia ser invadida pelas ervas daninhas dos pousios vizinhos etc. (BLOCH, Marc, op. cit., 2001b, p. 227-228). ${ }^{15}$ BLOCH, Marc, op. cit., 1960a, p. 40.
} 
primeira era semeada no outono para gerar o "cereal de inverno"; a segunda era destinada ao "cereal de primavera"; e a terceira permanecia em pousio durante o ano todo. ${ }^{16} \mathrm{O}$ objetivo dessas técnicas agrícolas era, ao mesmo tempo, impedir o desgaste do solo e garantir que sempre uma parte das terras ficasse em descanso, condição primordial para o exercício da vaine pâture. Somente uma decisão da comunidade podia alterar esse calendário. O proprietário não era, portanto, livre para explorar a sua terra de acordo com os seus interesses individuais. Como diz Laveleye, tratava-se de uma clara aplicação do princípio segundo o qual "o interesse geral prima sobre a propriedade privada e pode lhe impor limites. Apenas o direito anterior e superior da comunidade pode legitimar uma tal limitação do direito individual". ${ }^{17}$

Esse sistema de servidões coletivas (proibição de cercar, afolhamento obrigatório e, sobretudo, vaine pâture e parcours recíproco entre as comunidades) tornava possível a sobrevivência de muitos camponeses mais pobres. ${ }^{18}$ Desprovidos de parelhas e, muitas vezes, de terras, esses camponeses podiam, por meio do pasto coletivo, alimentar alguns animais, cujos produtos garantiam, ao menos, uma magra sobrevivência, sem depender totalmente do trabalho assalariado para agricultores mais abastados. Até mesmo para os pequenos proprietários, o pastoreio coletivo era um complemento indispensável à renda da terra. ${ }^{19}$

Esse sistema também beneficiava o senhor feudal que detinha, sobre esses direitos, certos privilégios. Assim como todos os habitantes da aldeia, ele se beneficiava do pasto coletivo, mas possuía, diferentemente dos demais, a faculdade de se subtrair à obrigação de juntar os seus animais ao rebanho comum da aldeia. Esse privilégio, que recebia o nome de troupeau à part (rebanho à parte), ${ }^{20}$ lhe permitia, portanto, compor um rebanho distinto, com um número quase ilimitado de animais e que poderia pastar livremente sobre os campos. A única restrição era a de não reduzir por completo o alimento dos demais animais,

\footnotetext{
${ }^{16}$ BLOCH, Marc, ibidem, p. 30-31.

${ }^{17}$ LAVELEYE, Émile de. De la propriété et de ses formes primitives. Paris: Librairie Germer Baillière, 1874, p. 337.

${ }^{18}$ Além dos costumes citados, outros direitos de uso incidiam sobre as explorações agrícolas. O glanage, por exemplo, dava aos habitantes da comunidade (sobretudo os velhos, crianças e deficientes físicos), após a realização da colheita, o direito de recolher, durante três dias, tudo o que restava nos campos. ${ }^{19}$ LEFEBVRE, George. La place de la Révolution dans l'histoire agraire de la France. In: Annales d'Histoire Économique et Sociale, tomo I. Paris: Librairie Armand Colin, 1929, 511. 20 Esse direito senhorial não vigorava em todo o território. Ele era particularmente forte na Champagne e na Lorena. No Béarn, ele recebia o nome de herbes mortes (BLOCH, Marc, op. cit., 2001c, p. 331).
} 
mas o troupeau à part, na prática, gerava muitos abusos. Esse direito, situado na intersecção entre os direitos coletivos e os direitos senhoriais, fazia dos senhores os maiores beneficiários dessa forma de organização da produção.

O troupeau à part era extremamente lucrativo para os senhores, sobretudo porque muitos deles arrendavam o privilégio a terceiros, por contrato específico ou com o conjunto do domínio. Os arrendatários eram, em geral, mercadores de animais, carroceiros e até mesmo açougueiros, ou seja, capitalistas estranhos à comunidade, que lucravam em cima de servidões em princípio instituídas para os aldeões. ${ }^{21}$

Em suma, os direitos coletivos beneficiavam, ao mesmo tempo, os pequenos camponeses que deles extraiam a sua subsistência, os senhores detentores de privilégios e seus arrendatários. Para esses grupos, não havia interesse na erradicação das servidões.

O mesmo não pode ser dito dos grandes proprietários de terras. Estes viam a vaine pâture e as servidões coletivas em geral como um insuportável entrave ao aproveitamento da terra. Esse ódio começaria a tomar forma a partir do momento em que, diante do aparecimento de novas técnicas agrícolas e novas ideias agronômicas, projetou-se abolir o pousio e realizar uma segunda colheita, algo que o pasto coletivo não permitia.

Proprietários e grandes fazendeiros queriam promover uma agricultura de tipo intensivo e acreditavam que os direitos de uso, na medida em que impunham o pousio, constituíam um grave obstáculo ao pleno aproveitamento do solo. Acusavam, aliás, a vaine pâture de sequer cumprir o seu objetivo fundamental, a alimentação do gado. O tipo de agricultura que queriam promover exigia uma forte adubação e a alimentação dos animais era, por isso, uma questão fundamental. Pregavam, assim, a utilização de novas técnicas, como a cultura de forragens (luzerna, sanfeno, trevo, túrnepos), ${ }^{22}$ plantas cultivadas especialmente para a alimentação dos animais e cuja produção permitiria renovar o solo sem submetê-lo ao descanso.

Bloch explica que algumas plantas forrageiras (como as leguminosas) deviam, para atingir o seu maior rendimento, permanecer, durante vários anos consecutivos, no mesmo solo. Outras (como as tuberculosas) eram anuais, mas, dentro do quadro de rotação de culturas, só poderiam ser plantadas após um ou dois anos dedicados aos cereais, ou seja, durante o período previsto para o pousio. Em ambos os casos, o afolhamento obrigatório, imposto pelo pasto coletivo,

\footnotetext{
${ }^{21}$ BLOCH, Marc, ibidem, p. 334.

${ }^{22}$ BLOCH, Marc, ibidem, p. 275.
} 
freava a cultura das forragens. ${ }^{23}$ Além disso, para muitos, os direitos coletivos, na medida em que eles garantiam a sobrevivência dos pequenos camponeses, privavam as grandes explorações de mão-de-obra.

Bloch vê nessa oposição entre dois tipos de agricultura (comunitária e intensiva) um confronto entre duas concepções de direito. ${ }^{24}$ Contra o caráter coletivo da propriedade rural, ganhava força a ideia de uma propriedade livre e individualizada. Assim, proprietários reclamavam o direito de cercar as suas terras, o que lhes permitiria subtraí-las à vaine pâture e implementar uma agricultura mais intensiva. Ao mesmo tempo, o cercamento dos campos revestia-se de um inegável caráter simbólico, consubstanciando a própria noção de propriedade individual.

Desde o século XVI, um movimento pelo fechamento das terras propagou-se pelas regiões do Norte, como Flandres e Normandia, mas a rigidez das regras costumeiras era difícil de ser vencida. A classe possuidora não dispunha de força política para tanto. ${ }^{25}$ Os proprietários buscavam geralmente obter, junto às autoridades judiciais e administrativas, uma decisão individual que lhes permitisse fechar as suas terras. Tais decisões costumavam gerar muitos protestos por parte dos aldeões. Além disso, elas eram raras, pois as autoridades tradicionalmente tendiam a apoiar as comunidades. Essa postura da administração mudaria drasticamente ao longo do século XVIII.

\section{Bens comunais e propriedade coletiva no final do Antigo Regime}

O coletivismo agrário manifestava-se igualmente pela existência de bens comunais, isto é, propriedades pertencentes à coletividade dos habitantes das comunas rurais. Em Propriété collective et identité communale (1998), Nadine Vivier aponta que os comunais sempre estiveram envoltos em polêmicas. Em 1782, La Maillardière, no seu tratado Le produit et le droit des communes, definia

\footnotetext{
${ }^{23}$ BLOCH, Marc, ibidem, p. 276. Muitos reclamavam ainda que a circulação dos animais entre as parcelas favorecia as epizootias e a deterioração dos campos (MALRAUX, Abbé de. Les moyens de détruire la mendicité en France. Reprodução da edição Châlons-sur-Marne: chez Paindavoine, 1780, p. 171). Além disso, a obrigação de ceifar em determinadas épocas decorria de uma decisão da comunidade pouco amparada na situação concreta de cada plantação. Com isso, muitas vezes, ceifava-se antes de atingida a maturação da colheita.

${ }^{24}$ BLOCH, Marc, op. cit., 2001c, p. 276.

${ }^{25} \mathrm{Na}$ Provença, as transformações foram mais fáceis e precoces. Isso se deve, de um lado, à prevalência, na região, de um regime de campos dispersos e largos, pouco adequados às práticas coletivas, e, de outro, ao peso do direito romano nos costumes locais (BLOCH, Marc, op. cit., 1960a, p. 224).
} 
os bens comunais como as terras "das quais os habitantes de uma mesma paróquia, ou vassalos de um mesmo feudo, detêm proprietariamente, por títulos ou posse, o gozo indiviso, oneroso ou gratuito [...] Patrimônio inalienável e perpétuo dos habitantes" ${ }^{26}$ Tal definição implicava, portanto, a ideia de que a titularidade do direito de propriedade sobre as referidas terras caberia a uma coletividade, a qual seria composta pelos habitantes da comuna rural. Assim, a fruição das terras comuns resultaria tão-somente da residência da pessoa na comunidade.

Essa é a visão que a Revolução faria prevalecer, mas, durante o Antigo Regime, a questão estava longe de ser pacífica. Muitos, por exemplo, viam os comunais apenas como "apêndices da propriedade privada". ${ }^{27}$ Eles seriam, assim, terras destinadas ao pastoreio dos animais dos proprietários e de seus fazendeiros. Essa concepção dava primazia ao direito da terra sobre o direito da pessoa. De acordo com a região, uma ou outra concepção prevalecia. Vivier cita até uma terceira corrente, pouco difundida, que atribuía os comunais aos membros da comunidade originária, cujo direito sobre as terras teria sido transmitido hereditariamente. ${ }^{28} \mathrm{Na}$ prática, entretanto, embora todos os habitantes usufruíssem das terras, eram os proprietários de bens fundiários os seus maiores beneficiários.

O comunal tinha múltiplas utilidades. Ele assegurava o suplemento de alimentação para os animais que nem os campos em pousio nem os prados eram capazes de prover. Além disso, as florestas comunais forneciam a madeira de que todos os habitantes da comunidade precisavam, além de muitos outros produtos silvícolas. As terras comuns também constituíam uma reserva de terra arável que podia eventualmente servir a uma cultura temporária. ${ }^{29}$ Nas épocas antigas, em que a agricultura ainda era pouco individualizada, não havia vida agrária possível sem os bens comunais. Eles eram complementos necessários

\footnotetext{
26 “[...] dont les habitants d'une même paroisse ou vassaux d'un même fief, ont propriétairement, par titres ou possession, la jouissance indivise, onéreuse ou gratuite [...] Patrimoine inaliénable et perpétuel des habitants" (citado em VIVIER, Nadine. Propriété collective et identité communale. Les biens communaux en France 1750-1914. Paris: Publications de la Sorbonne, 1998, p. 31).

${ }^{27}$ VIVIER, Nadine, ibidem, p. 49.

${ }^{28}$ VIVIER, Nadine, ibidem, p. 50.

${ }^{29}$ BLOCH, Marc, op. cit., 1960a, p. 181. A cultura temporária nos comunais era bastante praticada em algumas regiões, como Auvergne, Borgonha e Alsácia (VIVIER, Nadine, op. cit., 1998, p. 5152). Lefebvre explica que a receita dos comunais constituía um fundo especial, a massarderie, que servia para quitar os tributos comunais e os impostos reais, o restante sendo distribuído entre os chefes de família (LEFEBVRE, Georges. Les paysans du Nord pendant la Révolution française. Paris: Armand Collin, 1972, p. 66).
} 
para os grandes e médios exploradores e a garantia de sobrevivência para os camponeses mais pobres. ${ }^{30}$

Assim, a propriedade comunal dava aos habitantes da comuna a possibilidade de gozarem coletivamente das terras comuns e delas extraírem produtos necessários à sua subsistência. Poder-se-ia pensar, portanto, que os comunais eram bens sobre os quais pesavam apenas os direitos reais da coletividade, mas o fato é que, por força do direito feudal, sobre eles incidia uma multiplicidade de direitos que eram presididos pelos do senhor. A senhoria compreendia não apenas o domínio senhorial e as várias tenências, mas todos os espaços sobre os quais o senhor exercia o seu domínio, o que incluía os comunais. ${ }^{31}$ Embora não detivesse o domínio útil sobre o solo, a ele cabia o domínio direto que lhe dava a faculdade de arrecadar rendas sobre a utilização dos comunais pelos aldeões.

Além disso, tradicionalmente, os senhores procuraram usurpar essas terras, reservando-as à alimentação de seus animais. Em certos casos, quando as terras eram aráveis, eles procuravam arrendá-las em benefício próprio. Com isso, durante a Idade Média, os senhores reduziram substancialmente a extensão das terras comuns, sobretudo nas regiões onde o solo tinha mais valor. ${ }^{32}$ Os habitantes das aldeias resistiam apenas com grande dificuldade ao esforço senhorial de açambarcamento do patrimônio comunitário. Os conflitos entre senhores e aldeões prolongar-se-iam por todo o Antigo Regime.

A partir do século XVI, a tentativa da classe senhorial de reconstituir os grandes domínios reforçou os conflitos em torno dos comunais. Esse processo foi então acompanhado por uma tentativa, por parte dos juristas, de dar à propriedade uma definição mais precisa que superasse a concepção de domínio como um complexo de direitos superpostos. Era necessário determinar quem era o "dominus" das terras comunais. ${ }^{33}$ Duas concepções diferentes moveram esse debate.

De um lado, os jurisconsultos antigos, estudiosos do direito romano, admitiam a ideia de uma propriedade natural e original dos habitantes. Os senhores teriam, ao longo da Idade Média, se apropriado pela força das terras e concedido direitos de uso aos habitantes, como forma de povoar a senhoria. Não haveria, portanto, um título que legitimasse a "propriedade" dos senhores, pois esta seria o mero

\footnotetext{
${ }^{30}$ SOBOUL, Albert, op. cit., 1983, p. 205.

${ }^{31}$ BLOCH, Marc, op. cit., 1960a, p. 186-187.

${ }^{32}$ LAVELEYE, Émile de, op. cit., 1874, p. 328.

${ }^{33}$ BLOCH, Marc, op. cit., 1960a, p. 189.
} 
resultado da violência cometida contra os aldeões. Assim, os comunais pertenceriam, em razão de uma "posse imemorial da terra", à coletividade dos habitantes. ${ }^{34}$

Por outro lado, os feudalistas, estudiosos do direito feudal, entendiam os bens comunais como concessões dos senhores às comunidades. A origem dos bens remontaria, assim, à chegada dos francos à Gália: os conquistadores teriam repartido as terras entre si e concedido posteriormente certos direitos aos habitantes. Fundamentalmente, essa teoria promovia uma defesa do regime feudal. ${ }^{35}$

Embora o debate não tenha sido resolvido até a Revolução, durante os séculos XVII e XVIII, a teoria dos feudalistas foi utilizada para fundamentar o tradicional direito de triagem que seria regulamentado pelo edito de agosto de 1669. A triagem dava ao senhor o direito de obter $1 / 3$ dos bens comunais, em plena propriedade, abandonando, com isso, qualquer pretensão, mesmo que de mero gozo, sobre os $2 / 3$ restantes. ${ }^{36}$ Assim, entre 1669 e 1789 , o esforço dos senhores se deu no sentido de fazer valer o direito de triagem. Este era odiado pelos habitantes das comunas que não admitiam ver $1 / 3$ dos bens da coletividade serem apropriados pelo senhor. Para eles, a triagem nada mais era do que a admissão legal da teoria da propriedade senhorial sobre os bens. ${ }^{37}$ Robespierre chamaria a triagem de "um atentado à propriedade e aos direitos invioláveis do cidadão". 38

Muitas vezes, o senhor exercia pressão sobre a coletividade para que esta quitasse suas dívidas, o que a obrigava a vender os comunais, ou parte deles. A

\footnotetext{
${ }^{34}$ VIVIER, Nadine, op. cit., 1998, p. 42.

${ }^{35}$ VIVIER, Nadine, ibidem, p. 43. A autora mostra ainda que, dependendo das regiões, uma ou outra teoria prevalecia. Havia as regiões de "nulle terre sans titre" (nenhuma terra sem título) e as de "nulle terre sans seigneur" (nenhuma terra sem senhor) (p. 44).

${ }^{36} \mathrm{O}$ edito de 1669 impunha duas condições para que a triagem fosse realizada: que a concessão do terreno aos habitantes fosse gratuita e que os $2 / 3$ restantes fossem suficientes para atender às suas necessidades (BOURGIN, Georges. Les communaux et la Révolution française. In: Nouvelle Revue Historique de Droit Français. Paris: 1908, p. 695).

${ }^{37}$ Além da triagem, havia outro instituto bastante semelhante que recebia o nome de cantonnement. A triagem incidia sobre as terras das quais o senhor tinha o domínio direto, ou seja, terras supostamente concedidas gratuitamente pelo senhor aos habitantes das comunas. O cantonnement, por outro lado, pesava sobre as terras cuja concessão era onerosa e que eram, portanto, possuídas pela comunidade. Embora o fundamento jurídico fosse diferente, na prática, o resultado era o mesmo: 1/3 dos bens passavam para as mãos do senhor, em plena propriedade (VIVIER, Nadine. op. cit., 1998, p. 43). 38 "[...] un attentat à la propriété et aux droits inviolables du citoyen" (Moção em nome do Artois, da Flandres, do Hainaut e do Cambrésis, pela restituição dos bens comunais invadidos pelos senhores e contra o direito de triagem. In: ROBESPIERRE, Maximilien. Oeuvres, tomo VI. Paris: Phénix Éditions, 2000, p. 219).
} 
intenção do senhor era ele mesmo adquirir as terras, ou então reclamar, com base no direito de triagem, 1/3 dos bens ou das somas arrecadadas com a sua venda. ${ }^{39}$

Assim, às tradicionais usurpações senhoriais, vinham somar-se novas perdas que atingiam em cheio as comunidades camponesas. Estas encontravam algum consolo na proteção que a Monarquia tradicionalmente lhes concedia. Através das ordenações reais, o poder central procurava frear os abusos cometidos pela nobreza feudal e tomava o partido das comunas. No século XVI, as ordenações de Henrique III (27 de abril de 1567) e de Blois (maio de 1579) procuraram conter os excessos senhoriais, proibindo a usurpação das terras vagas ${ }^{40} \mathrm{e}$ dos comunais. Sob o reinado de Luís XIV, a ordenação de 1659 restabeleceu de pleno direito as comunas nas terras alienadas durante os vinte anos anteriores. A mais importante lei do período, entretanto, foi o edito de Saint-Germain-en-Laye, de 1667 , que decretou o retorno à comunidade de todos os bens comunais vendidos desde 1620, declarando nulos os atos de venda. ${ }^{41}$ Esse edito seria completado, em abril de 1683, por uma nova declaração que proibiria toda e qualquer venda não autorizada expressamente pelo intendente responsável. Assim, a defesa das comunidades pela administração real opunha os intendentes, funcionários da Monarquia, aos Parlamentos, defensores dos interesses senhoriais.

Por meio de anulações e proibições de vendas de comunais e triagens, a Monarquia protegia as coletividades, uma atitude que pode ser atribuída a razões fiscais e políticas. A apropriação de terras por senhores, amparados pelos seus privilégios fiscais, privava a administração central da arrecadação do imposto fundiário. Como diz Bourgin, "os reis, de fato, tinham por missão essencial proteger a paz social, e os tributos do Estado obrigavam-nos, além disso, a velar pela boa administração das finanças comunais, base das imposições nacionais". ${ }^{42}$ Além disso, a defesa da comunidade em face do poder senhorial era uma forma de fortalecer o poder central monárquico. Entretanto, a atitude da Monarquia mudaria consideravelmente na segunda metade do século XVIII.

\footnotetext{
${ }^{39}$ BLOCH, Marc, op. cit., 1960a, p. 191-192.

${ }^{40}$ As terras vagas (terres vaines et vagues) eram terras que, em geral, haviam sido concedidas às comunidades ou a particulares, mas que posteriormente foram abandonadas.

${ }^{41}$ LAVELEYE, Émile de, op. cit., 1874, p. 330-331.

42 "Les rois, en effet, avaient pour mission essentielle de protéger la paix sociale et les charges de l'Etat les obligeaient d'autre part à veiller à la bonne administration des finances communales, base des impositions nationales" (BOURGIN, Georges, op. cit., 1908, p. 693).
} 


\section{Tendências individualistas pré-revolucionárias}

\subsection{0 impacto das novas ideias}

Em meados do século XVIII, observar-se-ia uma mudança de mentalidade. A luta dos proprietários pela individualização da propriedade ganharia um novo impulso, com a difusão de novas correntes de pensamento que forneceriam a fundamentação teórica às suas pretensões. Muitas dessas novas ideias apontavam para a necessidade de promover um maior desenvolvimento agrícola por meio da introdução de formas de produção mais intensivas, o que implicava uma atenuação das práticas comunitárias.

Um grande impacto teria a publicação do Tableau Économique (1759), de François Quesnay, que se propunha a descrever a forma pela qual se opera a circulação das receitas. Nas poucas palavras e números que compõem a fórmula de Quesnay, estavam delineadas as bases para a construção do pensamento fisiocrata. ${ }^{43}$ Ao apontar a oposição entre "despesas produtivas" e "despesas estéreis" ${ }^{44} \mathrm{o}$ autor sustentava a noção de que apenas a indústria agrícola seria verdadeiramente produtiva, na medida em que, apenas nela, a riqueza criada ultrapassaria a riqueza consumida. ${ }^{45} \mathrm{Na}$ indústria e no comércio, não haveria propriamente criação de valor. Com base nessa ideia, Quesnay distinguia três classes sociais: a "classe produtiva”, voltada para a agricultura e responsável pelas receitas anuais pagas aos proprietários de terras; a "classe dos proprietários", que compreenderia não apenas os donos do solo, mas também os que exercem, a um determinado título, a soberania; e a "classe estéril", voltada para atividades outras que a agricultura (indústria, comércio, profissões liberais etc.). ${ }^{46}$

A teoria defendida por Quesnay e seus seguidores (Dupont de Nemours, Turgot, Lemercier de la Rivière etc.) implicava, portanto, que apenas o progresso agrícola poderia de fato gerar desenvolvimento econômico e produção de novas riquezas. Ao mesmo tempo, pregava a necessidade de proteger a propriedade

\footnotetext{
${ }^{43} \mathrm{O}$ surgimento do movimento fisiocrata é comumente apontado como o nascimento da ciência econômica: "Era verdadeiramente criar a ciência econômica e social" ("C'était bien véritablement créer la science économique et sociale". GIDE, Charles; RIST, Charles. Histoire des doctrines économiques: depuis les physiocrates jusqu'à nos jours. Paris: Librairie de la Société du Recueil J-B Sirey et du journal du Palais, 1909, p. 2).

${ }^{44}$ QUESNAY, François. Tableau Oeconomique. Versão microfilmada da edição original, Versalhes: 1759 , p. 2.

${ }^{45}$ GIDE, Charles; RIST, Charles, op. cit., 1909, p. 13.

${ }^{46}$ GIDE, Charles; RIST, Charles, ibidem, p. 21.
} 
pessoal, pois se é a agricultura que gera riqueza, é a propriedade que a torna possível: é o proprietário que confere à classe produtiva o instrumento da produção. ${ }^{47} \mathrm{O}$ próprio Quesnay afirmaria: "a segurança da propriedade é o fundamento essencial da ordem econômica da sociedade. Sem a certeza da propriedade, o território permaneceria inculto" ${ }^{48} \mathrm{O}$ pensamento fisiocrata daria impulso a um verdadeiro "culto da propriedade" que a Revolução francesa reviveria.

Essas novas ideias serviram de fundamento para a pregação de uma agricultura intensiva cuja implementação implicava uma revolução técnica. Para os adeptos das teorias econômicas, não havia dúvida: o ponto-de-partida necessário tinha de ser a eliminação do pousio. ${ }^{49}$ Era, portanto, necessário derrubar as servidões que pesavam sobre a propriedade. Aos argumentos econômicos, vieram então se juntar os argumentos jurídicos: se os costumes entravavam as possibilidades de crescimento da produção, eles também feriam a liberdade individual. ${ }^{50}$ Boncerf, no seu protesto em defesa da propriedade privada, chamaria o pasto coletivo de "costume louco e bárbaro" ${ }^{51}$ Mas essas razões teóricas eram fortemente alimentadas por razões mais práticas: o crescimento demográfico que havia marcado o século XVIII abria a terrível perspectiva de uma crise de subsistências. ${ }^{52}$

A questão, entretanto, não deixava de gerar polêmica. Para Bloch, o debate, na época, se dava "entre as necessidades da produção e a sorte das classes que o progresso ameaçava esmagar". ${ }^{53}$ As necessidades dos mais pobres não eram ignoradas pelos defensores da nova agricultura, mas estes acreditavam que apenas o "livre jogo das forças individuais" Para eles, o progresso que a eliminação da vaine pâture promoveria teria por

\footnotetext{
${ }^{47}$ GIDE, Charles; RIST, Charles, ibidem, p. 25.

48 “[...] la sûreté de la propriété est le fondement essentiel de l'ordre économique de la société. Sans la certitude de la propriété, le territoire resterait inculte" (QUESNAY, François. Maximes générales du gouvernement économique d'un royaume agricole. In: Oeuvres économiques et philosophiques. Frankfurt: J. Baer, 1888, p. 331).

${ }^{49}$ BLOCH, Marc, op. cit., 1960a, p. 217.

${ }^{50}$ BLOCH, Marc, op. cit., 2001c, p. 275.

51 "Cette coutume folle et barbare [...]". (BONCERF, Pierre-François. Les inconvénients des droits féodaux. Paris: Editions d'Histoire Sociale, 1976, p. 11).

${ }^{52}$ Esse temor era reforçado pelo fato de que a Guerra dos Sete Anos havia, por um momento, ameaçado cortar as fontes de abastecimento externas (BLOCH, Marc, op. cit., 2001c, p. 275).

${ }^{53}$ BLOCH, Marc, ibidem, p. 341.

${ }^{54}$ BLOCH, Marc, ibidem, p. 277.
} 
consequência necessária uma maior demanda por trabalho assalariado e compensaria, assim, as perdas dos camponeses menos afortunados.

O impacto das ideias fisiocráticas e agronômicas, impulsionadas pelo sucesso do sistema inglês das enclosures,${ }^{55}$ alimentaram as críticas não apenas aos direitos de uso (vaine pâture, parcours), mas também às propriedades coletivas. Para as novas correntes de pensamento, tratava-se de dois aspectos do mesmo problema. Assim como as servidões coletivas, os comunais passavam a ser vistos como instituições arcaicas e nocivas ao desenvolvimento da agricultura moderna e produtiva: pregava-se uma intervenção do governo que os transferisse para a iniciativa individual, a única capaz de tirar esses bens de seu deplorável estado de abandono. ${ }^{56}$ Agrônomos e fisiocratas queriam a regeneração da agricultura por meio da introdução de novas técnicas e entendiam necessário o arroteamento das terras comunais que, na sua maioria, permaneciam incultas e, muitas vezes, abandonadas. Muitos, como o marquês de Turbilly e Duhamel de Monceau, viam os comunais como um entrave à modernização do sistema agrícola e pediam a sua partilha. ${ }^{57}$ Para François Quesnay, "pai” do movimento fisiocrata, "esses Terrenos sendo possuídos pela Comunidade, não produzem um quarto do que renderiam se fossem divididos". ${ }^{58}$ Para os fisiocratas, na medida em que a terra era a base da riqueza nacional, era preciso encontrar meios de ampliar o espaço da produção agrícola. $\mathrm{O}$ arroteamento dos comunais era um

\footnotetext{
${ }^{55}$ A palavra enclosure é comumente utilizada para expressar o conjunto de transformações que, desde o final da Idade Média, marcaram a revolução agrária na Inglaterra. Assim como a França, o país tinha a maior parte de seu território submetido ao regime de campos abertos e alongados (openfields), nos quais as cercas eram proibidas em função dos usos comunitários (pastoreio, afolhamento obrigatório). Havia também os comunais, cobiçados pelos que queriam ampliar seus domínios. Como aponta Van Bath, a partir do final do século XIII, houve um esforço, na Inglaterra, para acabar com o sistema dos openfields, de modo a promover a substituição das pequenas explorações cerealíferas por grandes extensões destinadas à criação de gado ovino (produção de lã) (VAN BATH, B. H. Slicher. História agrária da Europa ocidental 500-1850. $3^{\mathrm{a}}$ ed. Lisboa: Editorial Presença, 1976, p. 167). Esse processo atingiria o seu auge durante o século XVIII. As enclosures consistiram numa série de transformações, geralmente, mas nem sempre, reunidas: estabelecimento de cercas em volta dos campos abertos; abolição das servidões coletivas; remembramento das parcelas, indispensável nas regiões de campos alongados; divisão dos bens comunais em proveito de explorações individuais (enclosure of commons) (BLOCH, Marc. Seigneurie française et manoir anglais. Paris: Armand Colin, 1960, p. 124-125).

${ }^{56}$ VIVIER, Nadine, op. cit., 1998, p. 25.

${ }^{57}$ Bloch entende que havia, por parte dos agrônomos, um certo exagero. Segundo o autor, a maioria dos comunais tinha permanecido inculta justamente por ser incultivável(BLOCH, Marc, op. cit., 1960a, p. 224). 58 “[...] ces Terreins étant possédés par la Communauté, ils ne produisent pas le quart de ce qu'il rendroient s'ils étoient divisés" (QUESNAY, François. Essai sur l'administration des terres. Reprodução da edição Paris: J.-T. Hérissant, 1759, p. 200).
} 
desses meios. $\mathrm{O}$ aspecto econômico da questão era, desta forma, colocado em primeiro plano. Ao mesmo tempo, o espírito individualista alimentava também a crítica às formas tradicionais da propriedade comunal.

O grande problema era decidir a quem deveria beneficiar a supressão da propriedade coletiva: aos grandes proprietários, como no sistema inglês, ou aos pequenos camponeses. Não havia unanimidade quanto à forma de realização da partilha. Havia os que, inspirados pela experiência inglesa, pregavam o desaparecimento dos comunais em proveito dos grandes domínios. Outros, como Quesnay, defendiam, por razões demográficas e fiscais, as vantagens da pequena exploração. ${ }^{59}$

Essas preocupações com a modernização da agricultura eram fortemente estimuladas pelo crescimento demográfico e o alto preço dos cereais. Crescia a busca por novas terras para o cultivo, o que fortalecia a corrente individualista. Cada vez mais, a repartição dos comunais e a sua exploração em parcelas individuais eram vistas como uma necessidade econômica.

\subsection{As tentativas de reforma}

Essas ideias não demorariam muito a repercutir na esfera administrativa, sobretudo a partir do final da década de 1760. Tradicionalmente defensoras das comunidades, as autoridades vinham, desde o início do século, mostrando-se cada vez mais favoráveis à ideia de uma segunda colheita que substituiria o pousio obrigatório dos campos. ${ }^{60}$ Diante do pronunciado crescimento populacional que o país conhecia, a possibilidade de uma má primeira colheita alimentava a constante ameaça da fome e dos motins populares que normalmente a acompanhavam. ${ }^{61}$ Nesse contexto, as novas doutrinas produziram um forte impacto. $\mathrm{O}$ desperdício do restolho inquietava os dirigentes e essa preocupação assumiria a forma de uma clara tendência individualista.

A revolução técnica que se queria promover chocava-se com as tradições da população camponesa que, na sua maioria, ainda era muito dependente dos direitos coletivos. Chocava-se também contra todo um sistema jurídico que era necessário repensar: essa foi a tarefa que os administradores se atribuíram

\footnotetext{
${ }^{59}$ Em seu Essai sur l'administration des terres, Quesnay propõe, por exemplo, uma divisão que daria dois arpents de terra por família (QUESNAY, François, ibidem, p. 200).

${ }^{60}$ BLOCH, Marc, op. cit., 1960a, p. 215-216.

${ }^{61}$ Sobre o tema dos motins da fome, é essencial a leitura da obra de George Rudé (cf. RUDÉ, George. A multidão na história. Rio de Janeiro: Campus, 1991).
} 
na segunda metade do século. Vários projetos de reforma foram elaborados e as primeiras medidas começaram a ser efetivadas em 1767. Autoridades locais (intendentes) foram, aos poucos, estendendo a sua proteção às terras particulares, atenuando o peso das práticas coletivas. Mas a Monarquia tinha em vista uma reforma mais profunda que foi marcada pelo embate entre duas concepções.

A questão da vaine pâture era disputada por duas figuras marcantes do final do Antigo Regime: de um lado, Bertin, controlador geral entre 1759 e 1763 e, em seguida, secretário de Estado, auxiliado, até janeiro de 1769, por Daniel Trudaine, organizador do Comitê de Agricultura; de outro, o marquês d'Ormesson, que, nos gabinetes do Controle Geral, concentraria, até 1773, os assuntos agrícolas. ${ }^{62} \mathrm{~A}$ esse conflito de competências correspondia um embate entre duas políticas agrárias diferentes.

Bertin sustentaria um projeto de reformas moderadas, baseadas num "prudente empirismo". ${ }^{63}$ Ele e Trudaine eram adeptos das novas ideias e da liberdade econômica. Buscavam trazer para a França o modelo inglês das enclosures que consistia num duplo procedimento: divisão das terras comuns em pequenas propriedades e reagrupamento dos open fields em parcelas maiores, protegidas por cercas e nas quais as práticas coletivas davam lugar a um uso privado irrestrito da terra. ${ }^{64}$

Em 1766, procuraram implementar um projeto de declaração real, para todo o reino, que teria por objetivo promover uma transição: não propunha a abolição da vaine pâture nem autorizava os particulares a se subtraírem a ela. Apenas permitia que até $1 / 5$ das terras dos cultivadores fosse protegido do pasto comum, sob a condição de que as parcelas fossem utilizadas para a criação de prados artificiais e que fossem protegidas por sebes ou fossos. As respostas a essa tentativa de reforma moderada foram pouco entusiastas. Uma nova deliberação foi tentada, mas não realizada. Seria então a vez de d'Ormesson.

Questões como a dos bens comunais e da vaine pâture estavam vinculadas aos problemas fiscais, o que credenciava o departamento de tributos, comandado por d'Ormesson, a reivindicá-las. Comparado a Bertin, o marquês demonstrava ser um adepto mais convicto das novas ideias econômicas e defendia reformas

\footnotetext{
${ }^{62}$ BLOCH, Marc, op. cit., 1960a, p. 225.

${ }^{63}$ BLOCH, Marc, ibidem, p. 225.

${ }^{64}$ BRADLEY, Harriett. The enclosures in England: An economic reconstruction. Kitchener: Batoche Books, 2001, p. 7.
} 
mais radicais. Ao mesmo tempo, entendia que, para que fossem bem-sucedidas, seria necessário atentar para os particularismos locais.

A sua reforma assumiria, assim, a forma de uma série de editos regionalizados, destinados a atenuar o peso das servidões coletivas. Até mesmo para d'Ormesson, a supressão pura e simples da vaine pâture era radical e perigosa demais, capaz de gerar uma incontrolável comoção popular. Sua ideia era atacar o pasto coletivo pela via indireta, eliminando as suas duas principais bases institucionais de sustentação: a proibição de cercar e o direito de parcours. A proibição das cercas era a condição material para a realização do pasto coletivo. Já o parcours recíproco entre as comunidades era um obstáculo a qualquer tentativa de reforma, pois submetia qualquer decisão a um acordo entre as aldeias vizinhas: um grupo isolado não poderia restringir por si só o pasto coletivo.

A ideia de d'Ormesson era a de promover uma política adequada às condições locais. Não emitiu uma medida só para todo o reino, como havia tentado Bertin, mas diversas leis de aplicação restrita às respectivas províncias. ${ }^{65}$ Esse esforço de reforma foi bastante intenso, mas de curta duração. Ao longo da década de 1770, o movimento seria desacelerado pela administração. Em 1773, as questões relativas à vaine pâture voltariam para Bertin. Sob sua administração, apenas um edito de cercamento, o do Boulonnais (1777), seria adotado, marcando o abandono da reforma projetada por d'Ormesson.

Os editos marcaram uma clara tentativa de ruptura com o direito anterior. Imediatamente após a sua promulgação, muitos proprietários cercaram as suas terras, protegendo seus campos dos direitos de uso. Isso gerou enorme insatisfação por parte da população camponesa que reagiu através de pedidos de revogação dos editos, processos judiciais e até mesmo derrubada de cercas. Muitos pequenos proprietários e exploradores aderiram à oposição, pois também dependiam da vaine pâture para a alimentação de seus animais. $\mathrm{O}$ apego do camponês aos costumes não podia ser facilmente vencido.

O alto custo das cercas também foi um sério obstáculo ao sucesso da reforma. A paisagem rural francesa era composta por campos muito alongados e estreitos, o que dava às cercas contornos extensos demais para a pequena superfície do

\footnotetext{
${ }^{65}$ Entre 1767 e 1777, diversos editos estabeleceram a liberdade de cercamento em várias regiões: Lorena, Trois-Évêchés, Barrois, Hainaut, Flandres, Boulonnais, Champagne, Borgonha, FrancoCondado, Roussillon, Béarn, Bigorre, Córsega. Entre 1768 e 1771, o parcours foi abolido na Lorena, nos Trois-Évêchés, no Barrois, no Hainaut, na Champagne, no Franco-Condado, no Roussillon, no Béarn, na Bigorre e na Córsega (BLOCH, Marc, op. cit., 1960a, p. 226).
} 
terreno. O regime agrário tornava-se, assim, um sério entrave à reforma jurídica. Teria sido necessário promover um remanejamento das terras, como no sistema das enclosures promovido na Inglaterra, ${ }^{66}$ algo que a Monarquia jamais tentou. ${ }^{67}$ Os lavradores eram adeptos das novas ideias e queriam aproveitar o restolho, mas não queriam ver sua liberdade condicionada à construção de cercas, caras demais para as suas pequenas parcelas. Os Cahiers de doléances de 1789 refletiram a insatisfação camponesa: muitos deles pediram a revogação dos editos.

Apenas os grandes proprietários, donos de parcelas maiores e capazes de financiar a construção de cercas, se beneficiaram das leis, sobretudo porque, embora protegessem suas terras do pasto coletivo, continuavam a usufruir dele nas explorações alheias, o que irritava ainda mais o pequeno camponês. Até mesmo os senhores ficaram divididos: eram grandes proprietários, mas também lucravam com o exercício ou o arrendamento do troupeau à part. Açougueiros e carroceiros também foram, portanto, atingidos. D'Ormesson não contava com tamanha resistência à sua tentativa de reforma. O entusiasmo em relação às novas ideias daria então lugar a uma certa prudência.

No que se refere aos bens comunais, verificou-se uma situação bem semelhante. Por força das novas teorias e das necessidades da nação, a Monarquia havia se convertido ao individualismo agrário ${ }^{68}$ No início da década de 1760 , algumas medidas traduziriam essa mudança de postura, como as decisões do Conselho de 16 de agosto de 1761 e de 8 de abril de 1762, e a declaração de 13 de agosto de 1766, que concederam isenção de imposto a todos os que arroteassem terras incultas. ${ }^{69}$

O conde d'Essuiles, autor de um importante tratado sobre a questão dos comunais, ${ }^{70}$ ficaria encarregado, a partir de 1766, de colaborar com o Controle Geral na elaboração de um programa de partilha. Essuiles descrevia os bens comunais como terras arrasadas e improdutivas que poderiam tornar-se férteis nas

\footnotetext{
${ }^{66}$ SÉE, Henri. La France économique et sociale au XVIIIè siècle. Paris: Librairie Armand Colin, 1933, p. 34-35.

${ }^{67}$ Lefebvre explica que a realeza temia que um remanejamento das terras desenraizasse o camponês, o que poderia abalar a percepção do imposto fundiário e aumentar a população vacante. Também os senhores, conscientes de que as rendas fundiárias, que compunham grande parte de seus ganhos, decorriam das tenências existentes, encaravam essa possibilidade com certo receio (LEFEBVRE, George, op. cit., 1929, p. 512).

${ }^{68}$ SOBOUL, Albert, op. cit., 1983, p. 188.

${ }^{69}$ BOURGIN, Georges, op. cit., 1908, p. 699.

${ }^{70}$ ESSUILES, Conte d'. Traité politique et économique des communes. Paris: 1770.
} 
mãos de exploradores particulares. Seu objetivo era demonstrar a necessidade da divisão do solo, como forma de beneficiar os mais pobres: as terras incultas ofereciam apenas um pasto magro e insuficiente e aproveitavam especialmente aos mais abastados, detentores dos maiores rebanhos. ${ }^{71}$

O projeto de Essuiles era o de conciliar os interesses dos pequenos camponeses e os dos grandes senhores, sem, ao mesmo tempo, lesar o patrimônio comunal. Sua proposta, marcada por um esforço de moderação, tentava implementar uma solução que fosse aceitável para todos. Propunha, assim, uma partilha igualitária, que seria instituída não por uma lei geral, válida para todo o território, mas, a exemplo do que havia ocorrido com os editos de cercamento, por medidas regionalizadas, adaptadas aos particularismos locais. Ao contrário do que pregava La Maillardière, que pedia a repartição obrigatória, Essuiles entendia a facultativa mais viável, dada a variedade das condições locais. ${ }^{72}$

A proposta de Essuiles não previa a partilha das terras em pequenas propriedades, mas apenas a repartição de gozo. Ou seja, a propriedade permaneceria com a comunidade; aos beneficiários, conceder-se-ia apenas o usufruto das terras. ${ }^{73}$ Era uma forma de permitir a exploração individual dos bens, sem, entretanto, afetar permanentemente o patrimônio comunal. Não havia, portanto, nesse projeto, uma contestação da noção de propriedade coletiva propriamente dita.

Essuiles sempre defendeu a tese de uma propriedade comunal que remontasse às primeiras instalações humanas. Pode, assim, parecer contraditório que o seu projeto incluísse a concessão do direito de triagem ao senhor: a realização da partilha pela comunidade daria ao senhor direito a 1/3 das terras. Longe de sustentar a tese dos comunais como uma antiga concessão senhorial, Essuiles buscava apenas, por pragmatismo, uma solução conciliadora que preservasse os interesses dos habitantes, mas sem romper com o sistema feudal. Foi, aliás, justamente por sua moderação que o seu projeto acabou se impondo. Vivier o situa entre o respeito ao regime feudal, a aplicação de princípios agronômicos e a preocupação com o campesinato menos favorecido. ${ }^{74}$

Sob a supervisão de d'Ormesson, no Gabinete das Finanças, auxiliado, desde 1766, por Essuiles, essas ideias seriam oficialmente adotadas e, a partir

\footnotetext{
${ }^{71}$ SÉE, Henri. Le partage des biens communaux en France à la fin de l'Ancien Régime. In: Revue Historique de Droit Français et Étranger, Paris: janeiro-março de 1923, p. 53-54.

${ }^{72}$ BOURGIN, Georges, op. cit., 1908, p. 697.

${ }^{73}$ VIVIER, Nadine. op. cit., 1998, p. 35.

${ }^{74}$ VIVIER, Nadine, ibidem, p. 34-35
} 
dos anos seguintes, dariam lugar a uma série de editos autorizando a partilha em diversas regiões do reino: Trois-Évêchés (junho de 1769), Lorena e Bar (junho de 1771), generalidade de Auch e de Pau (outubro de 1771), Borgonha, Mâconnais, Auxerrois e Bar-sur-Seine, Gex (janeiro de 1774), Bugey (janeiro de 1774), Alsácia (abril de 1774), Flandres (março de 1777), Artois (fevereiro de 1779) e Cambrésis (março de 1781). ${ }^{75} \mathrm{Na}$ década de 1780, a intensidade da atividade legislativa daria lugar a uma certa prudência, motivada pelos magros resultados obtidos pelos editos. Os pedidos de partilha não haviam sido muito numerosos. Para Sée, os editos fracassaram por terem tentado conciliar interesses opostos. ${ }^{76} \mathrm{~A}$ oposição às partilhas havia sido mais forte do que o previsto.

Vivier aponta que é difícil traçar um quadro geral das reações aos editos de partilha, pois cada grupo social reagia essencialmente em função das condições locais. ${ }^{77} \mathrm{O}$ projeto da Monarquia de tentar conciliar interesses contraditórios era impraticável diante das diversidades regionais. A priori, poderíamos pensar que, por conta do direito de triagem, a classe senhorial seria favorável à partilha. Ela de fato o foi em diversas regiões, como na Bretanha, mas a sua atitude foi heterogênea. Na Borgonha, por exemplo, a maioria dos senhores recusou a partilha. Como aponta Vivier, muitas vezes, os senhores conseguiam obter dos tribunais $1 / 3$ dos comunais em plena propriedade, sem a necessidade da partilha. ${ }^{78}$

Os camponeses mais abastados, maiores beneficiários dos comunais, recusaram a partilha. Acreditavam que, além de privá-los do pastoreio comum, a divisão dos bens e a concessão do uso de parcelas de terra aos habitantes da comuna prejudicariam a disponibilidade de mão-de-obra que empregavam na exploração de suas terras. São eles que adotaram uma atitude mais homogênea em relação à partilha. Apenas em algumas poucas regiões, como a Bretanha, a Normandia e a Auvergne, os proprietários foram favoráveis a ela, mas apenas porque acreditavam que ela dar-se-ia proporcionalmente às propriedades existentes. ${ }^{79}$

Os pequenos camponeses, por outro lado, viam-se diante de um dilema: preservar o pastoreio comum sobre os comunais ou possuir uma pequena parcela de terra. Sua atitude dependia de muitos fatores: o modo de repartição, a situação local das terras comunais, a extensão das usurpações antigas, a natureza

\footnotetext{
${ }^{75}$ VIVIER, Nadine, ibidem, p. 39.

${ }^{76}$ SÉE, Henri, op. cit., 1923, p. 57.

${ }^{77}$ VIVIER, Nadine, op. cit., 1998, p. 86.

${ }^{78}$ VIVIER, Nadine, ibidem, p. 58.

${ }^{79}$ VIVIER, Nadine, ibidem, p. 59-60.
} 
dos usos a que as terras estavam submetidas. ${ }^{80}$ Foram as condições locais que determinaram a postura de jornaleiros e trabalhadores agrícolas. Na Bretanha e nas regiões montanhosas, os comunais eram fundamentais para a alimentação dos animais, o que afastava qualquer possibilidade de repartição. Na Ile-deFrance, por outro lado, uma pequena parcela de terra garantiria a sobrevivência desses pequenos trabalhadores rurais. ${ }^{81}$

No geral, o princípio da partilha foi bem recebido onde a fome de terras era grande e onde as novas técnicas agrícolas já tinham sido implantadas, tornando rentáveis até mesmo os pequenos lotes de terra. Por outro lado, Vivier acredita que, mais do que as resistências locais, foi a "crescente paralisia dos poderes públicos" que levou ao fim do movimento dos editos de partilha. ${ }^{82}$ Mais preocupado com a questão financeira e temendo gerar novos conflitos, Calonne, controlador geral das Finanças entre 1783 e 1787, talvez considerasse a partilha inoportuna.

Bourgin acredita que, no geral, "a realeza praticou uma política totalmente favorável à partilha dos bens comunais". A ausência de uma lei geral explicarse-ia, assim, pela "incapacidade do antigo regime, reconhecida em outras matérias, de sistematizar seus regulamentos" ${ }^{83}$ A delicada questão dos comunais e o problema dos direito coletivos seriam retomados pela Revolução.

\section{A transformação revolucionária ${ }^{84}$}

A Monarquia do final do Antigo Regime não foi capaz de transformar as ideias individualistas da segunda metade do século XVIII em uma reforma profunda do direito de propriedade. Desde o seu início, a Revolução retomaria essas questões, embora com enormes dificuldades, dados os diversos interesses nelas envolvidos. A pressão pela abolição da vaine pâture era grande entre os proprietários rurais, mas a Assembleia temia que uma ruptura abrupta com os costumes antigos provocasse a ira das populações camponesas, ainda bastante dependentes dessa forma de organização da produção. Após muita discussão,

\footnotetext{
${ }^{80}$ BLOCH, Marc, op. cit., 2001c, p. 339.

${ }^{81}$ VIVIER, Nadine, op. cit., 1998, p. 60.

${ }^{82}$ VIVIER, Nadine, ibidem, p. 42.

${ }^{83}$ BOURGIN, Georges, op. cit., 1908, p. 706.

${ }^{84}$ Para os fins deste artigo, vamos apenas enunciar resumidamente as transformações promovidas pela legislação revolucionária. É possível encontrar maiores detalhes sobre esse aspecto em nossa dissertação de mestrado A propriedade sob a República jacobina: o impacto da legislação revolucionária sobre a questão fundiária (São Paulo, 2008). Disponível em: http://www.teses.usp.br/.
} 
solução viria apenas em 28 de setembro de 1791, com a adoção do decreto sobre os bens e os usos rurais e sobre a polícia rural, que ficaria conhecido sob o nome de Código Rural. A lei consagrava definitivamente a liberdade de cultura, ${ }^{85}$ derrubando com isso o afolhamento compulsório e a rotação forçada de culturas. O agricultor não era mais obrigado a submeter sua terra ao pousio. Quanto à vaine pâture, a lei adotava uma solução prudente, restringindo o pastoreio coletivo sobre as terras individuais, sem, entretanto, aboli-lo. Condicionava o seu exercício a uma justificação por título legal ou por um uso local imemorial e proibia-o sobre as terras semeadas ou cobertas por qualquer tipo de produção, protegendo com isso a agricultura intensiva. ${ }^{86} \mathrm{O}$ art. $4^{\circ}$ da Seção IV, por outro lado, derrubava a proibição do cercamento das terras, dando aos proprietários a possibilidade de protegerem suas terras dos usos tradicionais ${ }^{87}$ Se a Revolução relutava em abolir completamente os direitos e servidões coletivas, ela havia estabelecido as condições para o seu progressivo desaparecimento.

Quanto aos bens comunais, a questão foi objeto de inúmeros projetos ao longo dos primeiros anos da Revolução. Não havia consenso sobre a necessidade ou a viabilidade da partilha e, mesmo entre os seus adeptos, não havia consenso sobre quem deveriam ser os beneficiários. As discussões resultaram na lei jacobina de 10 de junho de 1793 que autorizaria a partilha dos bens comunais por cabeça, entre todos os habitantes domiciliados nos respectivos comunais, sem distinção de sexo ou idade, sendo as porções atribuídas em plena propriedade.

\footnotetext{
${ }^{85}$ Art $2^{\circ}$, Título I, Seção I: "Os proprietários são livres para variar à sua vontade a cultura e a exploração de suas terras, conservar à sua vontade as colheitas, e dispor de todas as produções de sua propriedade no interior do reino" "“Les propriétaires sont libres de varier à leur gré la cultur et l'exploitation de leurs terres, de conserver à leur gré les récoltes, et de disposer de toutes les productions de leur propriété dans l'intérieur du royaume". Archives Parlementaires, tomo XXXI, p. 431). 86 "A servidão recíproca de paróquia a paróquia, conhecida sob o nome de parcours, e que traz com ela o direito de vaine pâture, continuará provisoriamente a ser exercida, com as restrições determinadas na presente seção, quando essa servidão estiver fundada sobre um título ou uma posse autorizada pelas leis e os costumes. Nos demais casos, ela está abolida" "“La servitude réciproque de paroisse à paroisse, connue sous le nom de parcours, et qui entraîne avec elle le droit de vaine pâture, continuera provisoirement d'avoir lieu, avec les restrictions déterminées à la présente section, lorsque cette servitude sera fondée sur un titre ou sur une possession autorisée par les lois et les coutumes. A tous autres égards, elle est abolie". Archives Parlementaires, tomo XXXI, p. 432). 87 "O direito de cercar e abrir suas heranças resulta essencialmente do de propriedade, e não pode ser contestado a nenhum proprietário. AAssembleia nacional ab-roga todas as leis e costumes que possam contrariar esse direito" " "Le droit de clore et de déclore ses héritages, résulte essentiellement de celui de propriété, et ne peut être contesté à aucun propriétaire. L'Assemblée nationale abroge toutes lois et coutumes qui peuvent contrarier ce droit". Archives Parlementaires, tomo XXXI, p. 432).
} 
Essa autorização representou um golpe na propriedade coletiva e um reforço da pequena propriedade individual.

A Revolução conseguia com isso realizar aquilo que o Antigo Regime havia apenas esboçado. Embora, no plano das práticas sociais, as instituições de direito comunitário tenham permanecido vivas por muito tempo ainda ${ }^{88}$ a Revolução havia promovido a derrubada dos obstáculos institucionais à individualização da propriedade fundiária e à modernização da agricultura.

\section{Referências bibliográficas}

\section{Fontes}

Archives parlementaires de 1787 à 1860: recueil complet des débats législatifs et politiques des Chambres françaises. Première série, 1787 à 1799, fundado por MM. Mavidal e E. Laurent; continuado por M. L. Lataste,... M. Louis Claveau,... M. Constant Pionnier,... [et al.]. Reprodução da edição Paris: P. Dupont, 19041906, Les archives de la Révolution française, Pergamon press, 1990.

ROBESPIERRE, Maximilien de. Oeuvres. Paris: Phénix Éditions, 2000.

\section{Obras utilizadas como fontes}

BONCERF, Pierre-François. Les inconvénients des droits féodaux. Paris: Editions d'Histoire Sociale, 1976.

ESSUILES, Conte d'. Traité politique et économique des communes. Paris, 1770.

MALRAUX, Abbé de. Les moyens de détruire la mendicité ne France. Reprodução da edição Châlons-sur-Marne: chez Paindavoine, 1780.

QUESNAY, François. Tableau Oeconomique. Versão microfilmada da edição original. Versalhes: 1759.

QUESNAY, François. Essai sur l'administration des terres. Reprodução da edição Paris: J.-T. Hérissant, 1759.

QUESNAY, François. Maximes générales du gouvernement économique d'un royaume agricole. In: Oeuvres économiques et philosophiques. Frankfurt: J. Baer, 1888.

\footnotetext{
${ }^{88} \mathrm{~A}$ história da França constitui, sem dúvida, um caso à parte na história agrária do continente europeu, em função do grande peso da pequena propriedade camponesa. Esta sairia fortalecida da Revolução que, por meio da partilha dos bens comunais e da venda dos bens nacionais, procurou democratizar o acesso à terra. Isso conferiu à França uma via de desenvolvimento diferenciada que certamente manteve vivas certas práticas comunitárias tradicionais. Ao caso francês, opõe-se o da Inglaterra, onde as grandes enclosures do século XVIII "acabaram de jogar no proletariado rural, já antes bastante numeroso, uma grande parte da população camponesa” ("Elles ont achevé de jeter dans le prolétariat agricole, déjà nombreux auparavant, une grande partie de la population paysanne”. BLOCH, Marc, op. cit., 1960a, p. 129-139).
} 


\section{Bibliografia}

BLOCH, Marc. Les caractères originaux de l'histoire rurale française. Paris: Librairie Armand Colin, 1960a.

BLOCH, Marc. Seigneurie française et manoir anglais. Paris: Armand Colin, $1960 \mathrm{~b}$.

BLOCH, Marc. O problema dos regimes agrários. In: A terra e seus homens: Agricultura e vida rural nos séculos XVII e XVIII. Bauru, SP: Edusc, 2001a, p. 136-159.

BLOCH, Marc. O curso de Fontenay. In: A terra e seus homens: Agricultura e vida rural nos séculos XVII e XVIII. Bauru, SP: Edusc, 2001b, p. 200-260.

BLOCH, Marc. A luta pelo individualismo agrário na França do século XVIII. In: A terra e seus homens: Agricultura e vida rural nos séculos XVII e XVIII. Bauru, SP: Edusc, 2001c, p. 270-370.

BOURGIN, Georges. Les communaux et la Révolution française. In: Nouvelle Revue Historique de Droit Français. Paris: 1908, p. 690-753.

BRADLEY, Harriett. The enclosures in England: An economic reconstruction. Kitchener: Batoche Books, 2001.

GIDE, Charles; RIST, Charles. Histoire des doctrines économiques: depuis les physiocrates jusqu'à nos jours. Paris: Librairie de la Société du Recueil J-B Sirey et du journal du Palais, 1909.

LAVELEYE, Émile de. De la propriété et de ses formes primitives. Paris: Librairie Germer Baillière, 1874.

LEFEBVRE, Georges. Laplace delaRévolutiondansl'histoireagraire delaFrance.In: $A n$ nales d'Histoire Économique et Sociale. Paris: LibrairieArmand Colin, tomo I, 1929.

LEFEBVRE, Georges. Les paysans du Nord pendant la Révolution française. Paris: Armand Collin, 1972.

MALEZIEUX, R; RANDIER, R. Traité de droit rural. Paris: Librairie Générale de Droit et de Jusrisprudence, 1972.

RUDÉ, George. A multidão na história. Rio de Janeiro: Campus, 1991.

SÉE,Henri.Lepartage des biens communaux enFranceàlafindel'Ancien Régime. In:Revue Historique de Droit Français et Étranger. Paris: janeiro-março de 1923,p. 47-81.

SÉE, Henri. La France économique et sociale au XVIIIè siècle. Paris: Librairie Armand Colin, 1933.

SOBOUL, Albert. Problèmes paysans de la révolution 1789-1848. Paris: François Maspero, 1983.

VAN BATH, B. H. Slicher. História agrária da Europa ocidental (500-1850). $3^{\mathrm{a}}$ ed. Lisboa: Editorial Presença, 1976.

VIVIER, Nadine. Propriété collective et identité communale. Les biens communaux en France 1750-1914. Paris: Publications de la Sorbonne, 1998.

Recebido: outubro/2008 - Aprovado: junho/2009 